\title{
The healthcare system in Saudi Arabia: How can we best move forward with funding to protect equitable and accessible care for all?
}

\author{
Mohammed Khaled Al-Hanawi* \\ Health Services and Hospitals Administration Department, Faculty of Economics and Administration, King Abdulaziz University, \\ Jeddah, Saudi Arabia
}

Received: September 9, 2017

Accepted: October 17, 2017

Online Published: October 26, 2017

DOI: $10.5430 /$ ijh.v3n2p78

URL: https://doi.org/10.5430/ijh.v3n2p78

\begin{abstract}
The Saudi Arabian healthcare system is currently undergoing a process of reform. While it previously adopted a universal access approach in which all health care was provided free-of-charge to citizens at the point of care, this has been identified as unsustainable into the future. The shift towards an ageing population and the increasing burden of chronic disease, along with increasing use of technology and development of expensive treatments, mean that health care costs in Saudi Arabia are likely to increase significantly in the near future. Therefore, new ways to fund healthcare have been explored, with the solution proposed being a social insurance model in which employment contributions pay for care. This study seeks to identify the different alternatives which are available to the Saudi government and investigate the outcomes of these alternatives in their respective countries of use. The study examined the private insurance system in the United States of America, the social insurance system in Australia, the United Kingdom's National Health Service, and the Public Private Partnership adopted by Singapore. It would seem that the Singaporean model is associated with the lowest level of government spending to maintain a high quality of patient care. However, further in-depth analysis is required to better understand how this model would apply to the Saudi Arabian context.
\end{abstract}

Key Words: Healthcare financing, Health insurance, Saudi Arabia, Public private partnership

\section{INTRODUCTION}

The healthcare system in the Kingdom of Saudi Arabia (KSA) has improved rapidly over recent years. This may be attributed to the country's increased wealth and the high priority attached to providing citizens with high quality healthcare. ${ }^{[1]}$ The provision of free universal health care has helped ensure fair access to the whole population. However, economic experts and healthcare professionals have expressed concern over the feasibility of the current approach to fund- ing this system. ${ }^{[2-4]}$ The current level of provision alone consumed $7 \%$ of the governmental budget in $2013 .{ }^{[5]}$ Yet with a rapidly growing population, longer lifespan and shift towards Westernisation, ${ }^{[6,7]}$ demand is likely to increase. Added to this are projections that the current source of prosperity, oil, will become depleted in the very near future. ${ }^{[8]}$ Therefore, strategies to cope with these issues need to be designed and available to divert a potential healthcare crisis in the future.

In response to these concerns, the government has imple-

\footnotetext{
*Correspondence: Mohammed Khaled Al-Hanawi; Email: mkalhanawi@kau.edu.sa; Address: Department of Health Services and Hospitals Administration, King Abdulaziz University, Jeddah, 21589, PO Box 80200, Saudi Arabia.
} 
mented a new phased plan, which includes the introduction of a cooperative health insurance scheme, closely followed by privatisation of the nation's hospitals. ${ }^{[9]}$ However, other nations which have a well-established reliance on a similar approach have still experienced escalating healthcare costs. ${ }^{[10]}$ Experts have expressed concern with regards to the likely outcomes that will be seen if the current proposals continue with implementation. ${ }^{[1]}$ Moreover, there is a lack of research into whether alternative options would provide a better solution. This would be considered important from two perspectives. Firstly, as experts have expressed concern that the current proposals are not appropriate, there is a need for policy-makers to understand what other options are available and the different benefits and limitations of these options. Secondly, there is increasing pressure to apply the ethos of evidence-based healthcare to management in this area to better bridge the gap between management and professional practice that currently exists and improve patient care. ${ }^{[1]]}$

Comparisons of different healthcare funding mechanisms have been performed by other authors to help identify best practices in this area. ${ }^{[12]}$ Therefore, this study should also provide information which is useful for both researchers and policy-makers in identifying the best practice in healthcare system funding in the context of the KSA. This study, therefore, examines the different alternative finance options available, comparing the likely outcomes with the healthcare financing policy which is currently being put in place.

\section{LiterATURE REVIEW}

\subsection{Who pays for healthcare?}

Healthcare is conceptualised within the health economics literature as a market in which healthcare services represent the goods traded ${ }^{[13,14]}$ Although healthcare markets tend to be more complex and highly regulated than many other markets, economists would argue that concepts relating to market forces involving exchanges, rationing, supply and demand, and cost of production are still highly relevant. ${ }^{[13,14]}$ Assuming these generic economic models, healthcare products and services are modelled as goods, which can be viewed as either public or private. ${ }^{[15]}$

Public goods are those where there is a benefit to their production beyond that which is enjoyed by a single individual. ${ }^{[13]}$ Therefore, some aspects of healthcare can be considered as public goods, since provision is beneficial to the wider community. Examples of this include immunisation against and treatment of contagious disease. ${ }^{[13,16]}$ If this perspective is adopted, it can then justify the argument for a governmentfunded healthcare system. However, most components of healthcare do not meet this criterion. In fact, most health care which is provided today benefits only the individual receiving the treatment. For example, treatment provided for hypertension and cardiac disease would most likely only benefit the individual and their immediate family. ${ }^{[16]}$ If healthcare products and services are then viewed as private goods, this would seem to negate the argument for a government-backed system. However, this approach has been criticised as generating an increasing gap between healthcare and public health, a problem which Laurell ${ }^{[17]}$ argues is fraught with undesirable consequences for the population. To mitigate problems such as this, it is recognised that there are some private goods where public provision is the norm, including healthcare.

While different models for this situation have been described in the literature, normative or welfare models are most common, and argue for public provision as a means of reducing market imperfections and improving efficiency and social welfare. ${ }^{[18]}$ The requirement for public provision of private goods is also in keeping with recommendations put forth at the Alma-Ata International Conference on Primary Health Care in 1978, which identified universal healthcare coverage as a fundamental human right, implicating the role of governments in achieving this. ${ }^{[19,20]}$

\subsection{Approaches to healthcare financing}

There are various ways of classifying healthcare systems. In simple terms, healthcare systems can be publicly or privately funded and can also be publicly or privately operated. ${ }^{[15]}$ Field $^{[21]}$ described taxonomy of four types of healthcare systems: pluralist, insurance, health service and socialised systems. A pluralist system focuses on private provision and provides a high degree of autonomy to the healthcare professionals. An insurance-based system also includes a high degree of autonomy but focuses on the funding provided by third party insurance companies. The health service system also includes high levels of professional autonomy, but with state owned and funded facilities and care. Lastly, in the socialised system, the state owns all facilities and has control over the system. Further revisions of this taxonomy focused on the funding structures underlying healthcare systems, ${ }^{[22,23]}$ but most are criticised by Wendt and colleagues ${ }^{[24]}$ for the limited system components considered in the classification. One of the most widely used taxonomies is proposed by Schieber (1987) (cited in Wendt and colleagues ${ }^{[24]}$ ). This taxonomy divides healthcare systems into National Health Service, Social Insurance and Private Insurance models. The characteristics of these are summarised in Figure 1.

No country has adopted a wholly private or public healthcare system; there is always some level of government input. ${ }^{[14]}$ Most countries implement a mixed approach to healthcare provision, although the extent of the role of the private sector varies between countries. ${ }^{[14,25]}$ This to ensure that govern- 
ment is able to maintain some level of governance over the system and to address public health responsibilities. One of the main purported benefits of adopting a mixed publicprivate system is that it circumvents limitations associated with using either a completely public or completely private healthcare system. Furthermore, the mixed approach helps ensure that the ethical principles of care provision are met. ${ }^{[15]}$ From an economic and ethical standpoint, the mixed approach acknowledges that it is in the interest of the state to make some provisions, for example, in providing inoculations against diseases which have the potential to affect large parts of the population. Moreover, in ethical terms, it can be seen as morally wrong to subject the most vulnerable in the society to pure market-driven forces, as might be the case in the absence of state involvement. ${ }^{[14,15]}$
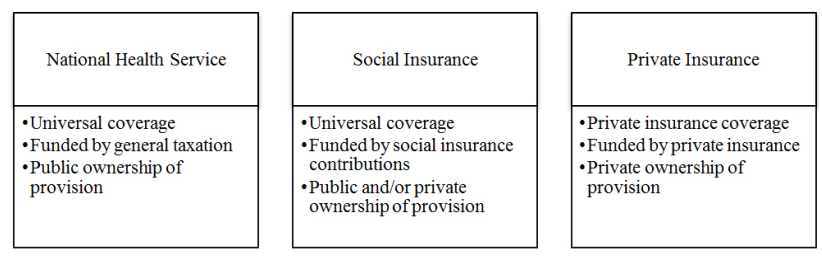

Figure 1. The characteristics of healthcare systems

\subsubsection{Government-funded healthcare system (national health services)}

The current healthcare system in KSA stems from the 1950s, when the Ministry of Health (MOH) was first established under royal decree. The decree stated that the government has a responsibility to provide healthcare for all citizens, a tenet which persists to the present day. ${ }^{[9,26,27]}$ This is similar to the social welfare principles underlying healthcare in other countries, for example the UK. Under these types of government-funded healthcare models, care is provided free at the point of use. The government uses revenues generated from tax to finance infrastructure and equipment, provision of services and supply of medical goods such as medications. ${ }^{[14]}$ There are few examples identifiable within the literature of healthcare systems which remain entirely public, with Canada being one of the only countries cited, although other studies identify Canada as taking a social insurance approach. $^{[19,28]}$

The NHS in the UK is one of the most notable examples of a government-funded model. This model advocates universal, comprehensive and free healthcare services at the point of access. ${ }^{[29]}$ Although the NHS is predominantly funded through general taxation, a proportion of funding in the NHS is derived from National Insurance (NI) contributions and from public charges such as prescription, dental and optical fees. ${ }^{[30]}$ About $£ 22$ billion from the total NI contributions in
2015-16 was allocated to the NHS, i.e. contributing to healthcare funding, with the remainder used for state pensions and other contributory and non-contributory payments. ${ }^{[31]}$

Most countries adopting government-funded approaches have showed concerns over its long-term sustainability and initiated proposals for reforms. ${ }^{[32]}$ For example, in the UK, huge backlogs with infrastructure maintenance have been reported with insufficient funding available to address the problem. This is illustrative of the larger problem of continued underfunding over a number of years. ${ }^{[33]}$ Yet as the level of funding required would be expected to continue to rise, it raises questions about how these deficits could possibly be addressed under current funding arrangements. Therefore, there too there is now an increasing pressure to reform the system of provision to maintain the principles set out by Bevan in the 1940s, but in a way which is sustainable into the future. Yet in spite of recognising that bringing the NHS to the marketplace is the best way to do this, ${ }^{[34]}$ the option to rely on insurance and privatisation has been resisted. This is not to say that private insurance is not available to ease some of the burden, as evidenced by its increasing availability and uptake. ${ }^{[35]}$ Other options have, however, formed the main arm of strategy, most notably a PPP or public finance initiative (PFI) approach. ${ }^{[36]}$

There remain problems other than funding infrastructure in adopting this type of approach. The desire to achieve high quality and equitable healthcare for all in the UK has stimulated debate over how best to achieve this. ${ }^{[37]}$ Solutions include pay-for-performance, integration of technology and development of new treatments for chronic conditions. However, all of these are expensive; leading the healthcare system to face ever increasing costs. ${ }^{[37-39]}$ Therefore, where publicly funded systems are already struggling, the problem would increase further in the future, as governments face pressures to cut spending on health.

\subsubsection{Private health insurance}

Health insurance is a system in which users pay regularly towards health system expenses in order to avoid bills that would levy an unacceptable burden on household budgets at the time of use. Private health insurance is defined as a contract between a policyholder and a third-party payer or government health programme to reimburse the policyholder for all or a portion of the cost of medically necessary treatment or preventive care provided by health care professionals. $^{[14]}$ Blomqvist ${ }^{[16]}$ argues that in private healthcare systems, there should always be some element of institutional insurance coverage due to the random occurrence of illness and disease, which may be financially disabling for sufferers. One of the best characterised private systems adopting this 
approach is the USA. However, there are many variations of the types of scheme adopted, with varied results observed regarding the effects on costs and patient outcomes. ${ }^{[40]}$

Today, private health insurance is available in most countries and is the norm in those relying on private sectors. ${ }^{[15]}$ Even in nations such as the United Kingdom (UK), there is some component of private healthcare provision, and therefore a market for private health insurance. ${ }^{[15,35]}$ Demand for this seems to revolve around issues such as waiting lists, ${ }^{[41]}$ with insurance to fund private provision viewed as a way to access better care. This is also true of countries in which there is a reliance on private provision, although the risk aversion also plays an important role. ${ }^{[14]}$ However, where there is an option to use publicly funded health or insurance schemes, these remain the more popular option, as evidenced by declining private insurance purchases where social schemes are introduced. ${ }^{[42]}$

\subsubsection{Social and public insurance systems}

Social health insurance systems are usually financed by employees and employers through contributions from payrolls (i.e. wage-related contributions), where the contributions are not related to the participant's health status. The financing mechanisms are based principally on social contributions. Unemployed individuals contribute a proportion of their unemployment benefit to maintain their insurance cover. If an individual has never been employed, their contributions are covered by a social fund.

Social insurance systems were first developed in the context of the workplace, as it was seen to be beneficial to employers to have workforces with access to better healthcare, especially in risky occupations where working conditions might affect health. Under this scheme, the employer would bear the cost of all or part of the insurance policy. ${ }^{[14]}$ Today, many countries have adopted a type of social insurance system in which there is one national insurance programme into which all employers pay. For example, in France all employers pay a portion of their employee's health insurance premium to a national programme, with the remainder paid by the employee. ${ }^{[3,44]}$ This can be distinguished from government-funded healthcare because the funds which are raised can only be used for healthcare provision. In contrast, funds raised through taxation can be reallocated to other areas. ${ }^{[14]}$ However, in some countries, such as France, additional money is also delegated from taxation of specific products, such as tobacco and alcohol, which are associated with recognised health effects. A second difference from government or tax-based systems is that social health insurance premiums are collected by a quasi-autonomous body, which is likely to provide better transparency. ${ }^{[14]}$

Published by Sciedu Press
In many of the systems operating social health insurance, including France and Germany, healthcare services are provided by a mixture of public and private providers. ${ }^{[43]}$ One of the limitations of this type of insurance-based system is that where increased costs are faced by the employer to pay for the insurance premium, this could result in reduced takehome pay for the employee. ${ }^{[14]}$ Moreover, those who are unemployed may be placed at a disadvantage. To overcome this, some countries have adopted a universal public insurance approach, an extension of the social insurance approach, to provide health coverage to the uninsured. In fact, most countries which rely heavily on private provision have had to concede and offer some form of social insurance policy. An example is the USA, where Medicare was introduced to assist the elderly, later followed by Medicaid for low income families. ${ }^{[45]}$

\section{Funding health care through insurance is complex and risky}

If private insurance is an effective way of accessing better healthcare, this could endanger the objectives of equity in healthcare in countries which opt for a predominantly public approach. One of the main problems is that many of those in lower socioeconomic groups are at risk of not being covered by an insurance policy. ${ }^{[15]}$ Even where people are covered by insurance, Phelan and colleagues ${ }^{[46]}$ argue that there is still a risk of widening health inequalities. This is due to market mechanisms in which those providing healthcare will seek to differentiate themselves by providing better quality services than their competitors. However, these are also likely to attract a higher price, so only those with higher income or those with better insurance policies would be able to afford them.

A similar situation is also seen in systems where both private and social insurance is available. Those with higher income would be able to access private insurance and therefore private, higher quality care, with others confined to the public system. Cuff and colleagues ${ }^{[47]}$ argue that private systems also have finite resources, so those with insurance may attain preference due to the willingness of insurance companies to pay higher prices than the government to secure resources for their paying clients. However, whether this is the reality has been debated with different studies examining different aspects of care and making comparisons difficult. ${ }^{[40,48]}$ Evidences from the USA suggest that quality of care is better for those with private health insurance than those with social insurance. ${ }^{[49]}$ Insurance companies provide policies at a premium which is carefully calculated. The premium needs to collect sufficient money over time to pay for predicted claims, administration costs and provide some profit to the company. As there is this need to also generate profit for the company, 
which is run as a business, this means that the user will typically pay more into a health insurance policy than they will take out over the long-term. ${ }^{[14]}$ However, it has been argued by some that the costs of administering insurance schemes and the marketing which they require generally results in quite low economic gains, ${ }^{[16]}$ which indicate that it may be difficult to price these within the reach of all members of a population.

When adopting insurance approach to healthcare, there is an element of moral hazard. ${ }^{[16,48]}$ This is described by McPake and colleagues ${ }^{[14]}$ as the risk that the individual will not take precautions to avoid unnecessary health costs. For example, when the individual does not have to pay at the point-of-use, they may be more likely to use healthcare services for trivial issues, which they could resolve through other means. Individuals may also be less likely to avoid expensive interventions that are either unnecessary or could be substituted with acceptable cheaper alternatives. ${ }^{[14,16]}$ This may then result in increased costs to the insurance company, and correspondingly, eventual increases in the costs of individual policies. There is also evidence from the USA that this system is still associated with increasingly greater costs. ${ }^{[50]}$ In fact, during the 1990 s and early 2000 s, the costs of healthcare to the USA government were much higher than for the Canadian government, in spite of all healthcare being provided publicly in Canada. ${ }^{51]}$ It could be argued that this represents better healthcare being available in the USA, but the World Health Organization (WHO) rankings would seem to disprove this, with Canada ranked 7 places above the USA. ${ }^{[52]}$ The main explanation may be due to the high proportion of the population which are not insured, for whom the government must pick up the costs. ${ }^{[50]}$ This is also added to shifts in the population distribution which have increased costs of social insurance schemes, for example with an ageing population leading to Medicare spending increasing consistently. ${ }^{[53]}$ In fact, there are moves in progress to address this, with the introduction of Obamacare, which seeks to improve the current system. ${ }^{[10]}$ There remain a huge swathe of critics of these changes to policy, however, and it would seem that more overhauls may occur in the near future to address the growing burden that health is placing on the American budget while making healthcare affordable and accessible for all. ${ }^{[54]}$

\subsubsection{Public private partnerships}

An alternative to privatisation of healthcare and subsequent use of insurance schemes is the use of public private partnerships (PPPs). PPPs are defined as a situation in which "the government mobilises private sector sources of funds to finance healthcare services". [15] PPP interfaces usually involve either engaging with for-profit organisations to access resources or with not-for-profit organisations for expertise or outreach. ${ }^{[55]}$ Small-scale PPPs already exist in many countries where there is non-governmental organisation (NGO) input into certain aspects of health, for example in research or provision of outreach clinics or delivery of certain aspects of public health. ${ }^{[55]}$ Another example is the PFI approach adopted by some local authorities in the UK, which is aimed at generating a new avenue of financing infrastructure components of the healthcare system. This is the area which has been reported as being a sink of a large quantity of funds in publicly-funded healthcare systems, so adopting a PFI approach has been heralded as a way to reduce this burden and free more funds for spending on actual healthcare services. ${ }^{[33]}$ However, Gaffney and colleagues ${ }^{[33]}$ highlight that it is a financing and not a funding initiative. This means that the funds which it generates must be paid back, so it provides a mode of deferring spending on infrastructure rather than preventing it. However, PFIs are not universal in the UK and there seem to be many more critics of the PFI approach than supporters. This is due to the higher than projected costs with which projects implemented have so far been associated and the evidence that care standards may have been lowered. ${ }^{[56]}$

In Singapore, there has been a much larger engagement of PPP. There, residents who are employed pay into a Medisave scheme along with their employers. ${ }^{[57]}$ This is similar to the social insurance schemes used in other countries, ${ }^{[4,44]}$ but in Singapore the money paid in acts more like a bank account, with payments for healthcare taken from the total amount available that has been paid in rather than full payments being made. If the individual dies, the remaining balance is then passed to the family. ${ }^{[57]}$ Any outstanding payment is made by the patient as an out-of-pocket expense, or through supplementary private insurance schemes. This means that provision is by private companies, as with systems reliant on insurance, ${ }^{[43,44]}$ but finance is also private as it is paid for by individuals and their employers directly from these Medisave accounts. There remains some public expenditure, but this can be focused to a greater extent on smaller numbers of public providers for those not working or with little in their Medisave account. ${ }^{[57]}$ There is also the benefit that people are forced to pay into the system, unlike in the USA, which should lead to less people being left without coverage, which is a source of much government spending at present. ${ }^{[50]}$ PPPs can possibly lead to inequalities and poor levels of care for some segments of the population. ${ }^{[55]}$ Conflicts of interest can also see huge profits generated for investors, with individuals or the government ultimately bearing the costs, as seen in examples such as PFIs in England. ${ }^{[58]}$ However, this would not be expected to differ substantially from privatisation which would be seen with the introduction of a social 
insurance policy, which would still see most care shift to private providers.

\subsection{Summary of findings}

The literature review showed numerous variations on the mix of public and private funding and provision of healthcare. Different approaches are summarised in the conceptual model provided in Figure 2. Based on this evaluation of the current literature, it is argued that there are benefits and limitations associated with each of the funding options avail- able to the Saudi government, which are also summarised in Figure 2. Yet there is currently no published evidence to demonstrate that the adoption of an insurance-based, privatised provision model would be the best approach to reducing current levels of spending on healthcare, remaining sustainable into the future. The proposed study therefore aims to address this gap in the literature, and comparing the different models of healthcare financing which are available based on the results achieved by other countries.
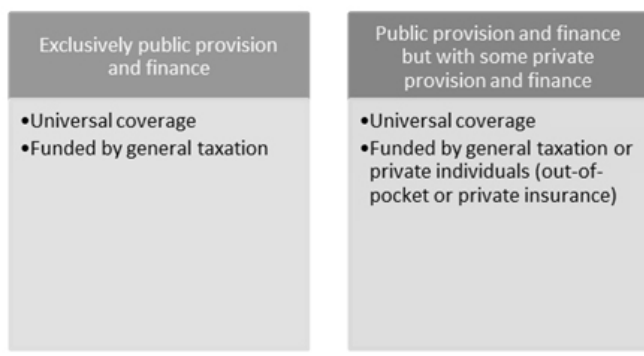

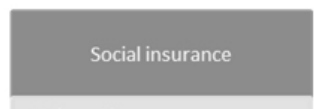

-Universal coverage -Mix of public and private provision

-Publicly funded but with dedicated source of funds social insurance contribution

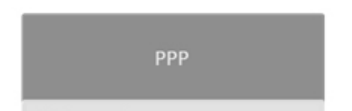

- Universal coverage -Mostly private provision with some public providers -Mostly privately funded by individuals, employers with mandatory savings scheme and private insurance top-ups -Public funding focused on those in need

EXAMPLES OF COUNTRIES ADOPTING THIS APPROACH

\begin{tabular}{|c|c|c|c|c|}
\hline & $\begin{array}{l}\text { UK } \\
\text { Denmark } \\
\text { Italy }\end{array}$ & $\begin{array}{l}\text { Australia } \\
\text { Germany } \\
\text { Mexico }\end{array}$ & Singapore & U.S. \\
\hline \multicolumn{5}{|c|}{ BENEFITS } \\
\hline $\begin{array}{l}\text { Equitable access for all } \\
\text { High level of governance }\end{array}$ & $\begin{array}{l}\text { Reduced public costs } \\
\text { Competition may improve } \\
\text { provision quality }\end{array}$ & $\begin{array}{l}\text { Competition may improve } \\
\text { provision quality } \\
\text { Funding can't be } \\
\text { reallocated elsewhere }\end{array}$ & $\begin{array}{l}\text { Public spending focused } \\
\text { where required } \\
\text { Competition may improve } \\
\text { provision quality }\end{array}$ & $\begin{array}{l}\text { Competition may improve } \\
\text { quality }\end{array}$ \\
\hline $\begin{array}{l}\text { Government bears all } \\
\text { costs } \\
\text { No choice for patients } \\
\text { Will become increasingly } \\
\text { difficult to finance with } \\
\text { more expensive } \\
\text { developments }\end{array}$ & $\begin{array}{l}\text { Inequitable access to } \\
\text { different providers } \\
\text { Will become increasingly } \\
\text { difficult to finance public } \\
\text { provision with more } \\
\text { expensive developments }\end{array}$ & $\begin{array}{l}\text { LIMITATIONS } \\
\text { Costs ultimately borne by } \\
\text { the patient } \\
\text { Access varies where } \\
\text { private insurance is also } \\
\text { available } \\
\text { Moral hazard }\end{array}$ & $\begin{array}{l}\text { Conflicting agendas could } \\
\text { lead to increased costs } \\
\text { and poorer care }\end{array}$ & $\begin{array}{l}\text { Inequitable access } \\
\text { Costs associated with } \\
\text { uninsured populations } \\
\text { Poor access to insurance } \\
\text { for disadvantaged groups } \\
\text { Moral hazard }\end{array}$ \\
\hline
\end{tabular}

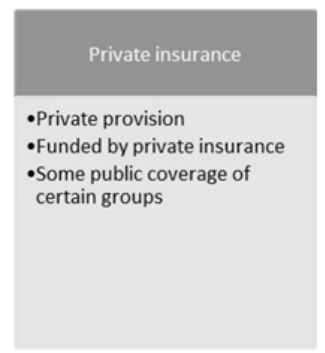

4

Figure 2. Conceptual model developed from the literature review and used to guide the remainder of the study

\section{RESEARCH AIMS AND OBJECTIVES}

There would seem to be three main options currently available to the Saudi government for future healthcare funding: to do nothing, to adopt a health insurance, or to adopt a procurement or PPP model. The aim of this study is to compare these different models of healthcare financing, based on the results achieved by other countries.

To achieve the research aim, the study addresses each of the following objectives:

(1) To identify, via a review of the literature, methods of healthcare financing which are currently adopted in countries which take a similar approach to healthcare as that taken in Saudi Arabia and face similar health problems.

(2) To collect data from secondary sources on the outcomes associated with each of the different financing systems including financial expenditure and healthcare quality outcomes.

(3) To compare the outcomes associated with the different financing methods and identify their associated limitations.

(4) To generate recommendations, on the basis of the data analysis, of which approach would be most appropriate to adopt in the KSA context. 


\section{RESEARCH METHODOLOGY}

The study utilised secondary data which is already available in the public domain. Collection of primary data on costs and outcomes of different nations' healthcare systems would be beyond the bounds of practicality and is not needed when quality data is already available. ${ }^{[59]}$ The methods of other studies comparing the performance of healthcare systems were adapted to focus on measuring healthcare costs associated with each system. ${ }^{[60]}$

\subsection{Study design}

There are a number of different approaches for evaluating the likely outcomes of different economic approaches to healthcare, though the best method is not agreed upon. ${ }^{[61]}$ The study adopted an approach which focused on performing cost-benefit analysis (CBA) comparisons between different types of healthcare system. There are a number of different methods for comparing the costs and benefits of different healthcare approaches. This type of healthcare system evaluation provides important information for future funding decisions, as these should be taken with the aim of not only reducing spending, but also maintaining high quality patient care. ${ }^{[60]}$ The different options are discussed here, as a basis for justifying the use of a CBA.

Human capital approach: This focuses on the productivity of the individuals within different systems, ${ }^{[62]}$ and is used in healthcare as a measure of quality of life. ${ }^{[63]}$ This approach could be considered relevant here given that subsequent productivity will influence the level of income generated by taxation or contribution to a social insurance scheme. However given that there are many other factors which may influence productivity, such as lifestyles, economic and political factors, ${ }^{[64]}$ it would be difficult to attribute differences solely to the healthcare system in that country.

Cost-effectiveness analysis (CEA): This is a decision-making tool used for comparing different interventions. ${ }^{[65,66]}$ This approach combines the overall net cost associated with an intervention and its outcomes, producing a ratio which also considers its effectiveness. This ratio is then compared with other interventions, and the best ratio is selected. ${ }^{[65]}$ There seems to be widespread support for the use of CEA in policymaking decisions regarding healthcare. ${ }^{[67]}$ One of the criticisms of this approach is that CEA can be overly simplistic, attempting to place a single value on the final end-point associated with a given approach. This can make it difficult to compare interventions which have different costs and endpoints associated with them. ${ }^{[65]}$ Determining the costs to be included of different interventions has also been identified as a potential issue of debate, ${ }^{[66]}$ although this would seem to be more straightforward where health expenditure in the different systems is concerned.

Cost-utility analysis (CUA): This is similar to CEA, but has been proposed as a better healthcare evaluation tool as it attempts to use outcome measures that can be calculated consistently across interventions, usually quality-adjusted life years (QALYs) or similar alternatives. ${ }^{[65]}$ This focuses on the greater overall effect of different healthcare interventions rather than solely the end-points, meaning it should more accurately reflect the wider implications of different approaches. ${ }^{[68]}$

Cost-benefit analysis (CBA): The main limitations associated with both CEA and CUA are that they are predominantly designed to assess the costs and outcomes associated with individual healthcare interventions rather than whole-system approaches. Therefore their utility in addressing the aim of this study, which focuses on whole healthcare system implications, could be questionable. Instead, a CBA was selected as a more appropriate tool, which has been more widely applied to analysis of wider policy rather than just individual interventions. ${ }^{[60,69]}$ A further benefit is that it accounts for all costs and benefits, regardless of who these affect, including health-related, monetary and other benefits and costs equally. ${ }^{[70]}$ It adopts a more narrative approach, rather than attempting to place a numerical value on inputs and outcomes, which is more suited to the type of data to be analysed here for quality of care.

As a CBA approach was selected, the study consisted of two key components: an analysis of the costs associated with the different systems and an analysis of the benefits, measured according to the quality of the care provided. This is very similar to the approach described by Feacham and colleagues, ${ }^{[71]}$ although they grouped benefits together under the term "performance". It was therefore important to determine the most appropriate components to include in the measurement of costs and benefits, as evaluation of these constructs has previously been noted to be one of the main difficulties faced in the CBA approach. ${ }^{[65]}$

Healthcare provision was measured in terms of inputs and usage. Inputs measured included the overall budget allocated to healthcare and overall spending, staffing levels and bed numbers. The costs of these different components of health were broken down into costs per capita and compared between systems. Services usage was measured in terms of the use of primary, secondary and tertiary care services, including bed occupancy rates. ${ }^{[71]}$ Considering the level of services provided and their overall usage is important to determine whether costs are a result of increasing provision, whether or not associated with increasing demand, or increasing costs associated with the existing services. ${ }^{[72]}$ It may also help 
to determine equity. ${ }^{[73]}$ Wendt and colleagues ${ }^{[24]}$ argue that there are six different components of the relationship between financers, service providers and the public which need to be considered when evaluating healthcare funding, which are summarised in Figure 3.

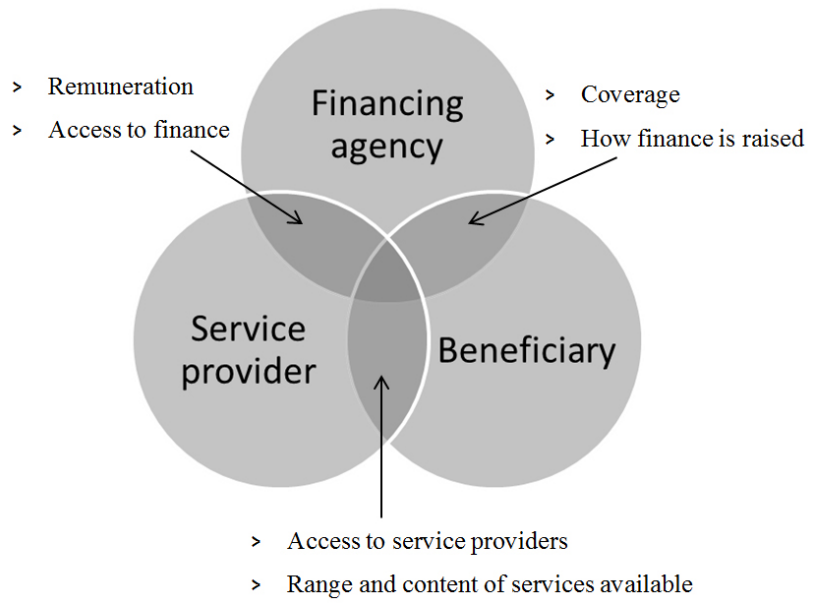

Figure 3. The relationship between financing agencies, healthcare service providers and beneficiary (patients) and the different areas to consider within each pairing (adapted from Wendt and colleagues ${ }^{[24]}$ )

There are various implications of adopting different healthcare funding systems, other than the level of finance which these different systems are able to provide. Different systems can affect the ownership of the institutions providing healthcare, which can have major implications for their employees and service users. They can also affect internal governance structures, as well as the flow of resources within the overall healthcare system. All of this is likely to have repercussions for the quality of care which can be provided. ${ }^{[14]}$ Therefore, it is important that the general context of the healthcare system be considered.

Qutub and colleagues ${ }^{[19]}$ describe a minimum set of components on which data must be collected to provide a comprehensive comparison between healthcare systems in different countries, which include the following:

- Context: Location, political system, population and age distribution, health indicators and determinants of health (human development index: life expectancy at birth, literacy rates, gross domestic product [GDP] per capita; infant mortality rates; health expenditure [\% of GDP])

- Ownership: Ownership status of infrastructure and land

- Delivery: Private or public, method of funds delivery, personnel constitution, community or institutionalised health facilities
- Financing: Source and methods of raising funds (tax, national insurance, private insurance, individual outof-pocket)

- Organisation: Structure (centralised/de-centralised), integration, accountability

- Target groups: Universal coverage or targeting of specific groups

- Comprehensiveness: Hospital/medical/drugs/dental/home care

- Outputs and outcomes: Utilisation and provision of different services; measures of health status

These would seem to cover the considerations outlined by Wendt and colleagues, ${ }^{[24]}$ so data on context, ownership, delivery, financing, organisation, target groups and comprehensiveness was also collected in addition to costing information. Outputs and outcomes are discussed in greater depth below.

It was important in ensuring the validity of the work that appropriate parameters were used to measure the performance of the different healthcare systems included in the analysis. ${ }^{[74]}$ There are numerous markers which may be used to evaluate the quality of healthcare provided in a system. Feacham and colleagues ${ }^{[71]}$ based their quality evaluation on vaccination rates, cancer screening, care for common conditions, and transplantation. However, the healthcare systems which were evaluated were those of the USA and UK, where different conditions may form the priority of healthcare providers. Also, some of these were difficult to find data on for systems outside of these countries. Consequently, it is appropriate to consider other markers as an evaluation of healthcare quality for this study, as healthcare systems from different countries are considered, not all of which are at the same stage of development as these Western nations. Therefore more general measures of population health were also included, as detailed under context in the model described by Qutub and colleagues. ${ }^{[19]}$

\subsection{Study methods}

As there was a desire to include healthcare systems in the comparative analysis which were representative of the major approaches to healthcare funding available, a non-probability purposive sampling approach was appropriate. ${ }^{[75]}$ A number of countries were already discussed in the literature review and the approaches taken by some of the world's best healthcare systems are identified in Figure 2. Therefore countries were selected from those whose system had already been classified.

There was a desire to understand the potential for different funding approaches to offer a viable alternative to the model proposed for Saudi Arabia. It was assumed that the potential 
of the different approaches would be reflected, at least to some extent, in the healthcare system performance of other countries in which they were currently adopted. Therefore countries for inclusion in the sample were preferentially selected if they were located above Saudi Arabia in the WHO ranking of healthcare system performance, as described by Tandon and colleagues, ${ }^{[52]}$ or were not substantially below it in the index. However, consideration was also given to the quantity of information which was available on the different systems, as some countries have far more information available in the public domain than others. For example, although the USA is ranked at number 37, compared to Saudi Arabia at number 26 , this is the best characterised healthcare system which currently adopts a predominantly private approach to healthcare.

The four countries which were selected on this basis for inclusion in the study were UK, Australia, Singapore, and the USA. These four countries' healthcare systems were analysed and compared with the system of Saudi Arabia, to demonstrate the difference between these systems and engaging in no change. The USA is considered prior to the introduction of Obamacare as this is when data is readily available and the analysis is interested in this system as an example of a private insurance-based one.

\subsection{Data sources}

A number of previously published studies were used as a source of information on the organisation of healthcare in the selected countries. Data was extracted where possible from the Organisation for Economic Co-operation and Development (OECD), ${ }^{[76]} \mathrm{WHO}^{[77]}$ and World Bank, ${ }^{[78]}$ who collect data on various indicators. When not available, data was extracted from previously published reports, studies and books. Care was taken to ensure that the data from different sources related to the same time period. Efforts were made to ensure that data was from the recent years for all systems to ensure that it reflected the current system.

\subsection{Ethical considerations}

As no human participants were used in the study, the main ethical concern was that the data collected was reported accurately. ${ }^{[79]}$ Therefore, this study has attempted to provide information on the sources of secondary data which were accessed. This should improve the replicability of the study and therefore ensure it is reliable. ${ }^{[74]}$ It was also important that the methods used for data collection were considered in the analysis of the data and the implications of these considered in the interpretation of the data. ${ }^{[79]}$

\section{RESEARCH RESULTS}

Tables 1-5 present a summary of the data collected which describes the structure of healthcare services in the analysed countries. Table 6 presents information on the context of the different populations served by these healthcare systems. Table 7 presents a comparison of the costs of the different systems. Table 8 presents information on the inputs and use of the different healthcare systems. Table 9 presents data on the overall quality of care which is offered by the healthcare systems examined.

\section{Discussion}

There are a number of different options currently open to policy makers in KSA regarding the future of funding for healthcare. The first option to the MOH is to simply alter their strategy for approaching health. This would require no direct change to the way in which the healthcare system is funded, but would instead require a shift towards focusing on prevention and better management of chronic conditions. ${ }^{[10]}$ This is largely the approach which has been taken over the past decade however, yet has so far been associated with ever increasing spending, ${ }^{[5]}$ so is unlikely to represent a sustainable solution.

The results showed that KSA is spending much less than other countries on healthcare. The overall health expenditure in the KSA is $\$ 680$ per capita compared to $\$ 2,273$ in Singapore and $\$ 8,362$ in the USA. This was also a much lower cost to the government than in any of the other countries, at $\$ 427$ per capita compared to $\$ 1,733$ in Singapore and $\$ 4,437$ in the USA. The remainder of the money which is currently spent on healthcare is from private spending, either out-of-pocket expenses, private insurance or from employer schemes. This lower level of spending in the KSA also seems to be reflected in the quality of care which is provided. KSA certainly provides care which can match other high quality healthcare systems, for example in terms of its immunisation rates, which are actually better than those of other countries examined. This may reflect the emphasis placed on improving rates of childhood and infectious diseases in the region over the past few decades. ${ }^{[9]}$ However, the KSA offers a much lower level of hospital and primary care services than other countries examined. For example, the number of doctors and nursing staff per 1,000 people are much lower compared to most of the other countries examined and the number of hospital beds is also much lower. This may contribute to the lower life expectancy and infant mortality which are also seen in KSA. It would therefore be desirable for overall healthcare spending to be increased if KSA is to continue to compete with other systems as one of the highest quality healthcare systems in the region or even in the world. ${ }^{[7,9]}$ 
However, it has already been identified that even current levels of government spending are unlikely to be sustainable into the future. ${ }^{[2-4]}$ Therefore, additional resources will be needed if the country is to meet the increasing challenge presented by non-communicable and chronic disease. ${ }^{[6,7]}$ This is a problem which would be expected to develop as the KSA becomes more Westernised and consumerist, bringing the type of problems seen elsewhere with obesity, diabetes and heart problems. ${ }^{[80,81]}$ There will also be increasing costs if the age distribution continues to change, as at present the older population in the Kingdom is much lower than in other countries examined, and it is this population which are likely to require the most healthcare intervention. ${ }^{[6,7,82]}$ Therefore, simply doing nothing is not an option.

Table 1. The data on the organisation of the KSA healthcare system

\begin{tabular}{|c|c|}
\hline Item & Public (government) and private \\
\hline Delivery & $\begin{array}{l}\text { - Public sector completely delivered by government: MOH and numerous independent government bodies } \\
\text { (other-government sector) such as the National Guard, Armed Forces, Ministry of Education } \\
\text { - Public sector health is free } \\
\text { - Personnel include: doctors, dentists and assistants, nurses, pharmacists, allied health professionals, } \\
\text { technical and administrative personnel } \\
\text { - Private sector delivered by individual investors or privately-owned companies } \\
\text { - Personnel are similar to public sector }\end{array}$ \\
\hline Ownership & $\begin{array}{l}\text { - Government sector completely owned by government } \\
\text { - Private sector is owned by individuals or companies, are independent of each other and self-governing }\end{array}$ \\
\hline Financing & $\begin{array}{l}\text { - Government sector completely delivered by government: } \\
\text { - Healthcare personnel: Salaried } \\
\text { - Facilities: Funded by annual budgets } \\
\text { - Private sector is funded through private insurance schemes or individuals out-of-pocket payment: } \\
\text { - Healthcare personnel: Salaried or fee-for-service } \\
\text { - Facilities: Budgets or fee-for-service, set by owners }\end{array}$ \\
\hline Organisation & $\begin{array}{l}\text { - Public healthcare: } \\
\text { - Decentralised: Regional health authorities take responsibility for strategic planning, policy-making and } \\
\text { supervising delivery of care } \\
\text { - Vertical integration: Primary, secondary and tertiary care } \\
\text { - MOH accountable for planning, training, human resources (HR), health outcome monitoring, financing } \\
\text { and coverage } \\
\text { - Private sector: } \\
\text { - Primary, secondary and tertiary care, but not integrated } \\
\text { - Licensing and health policies which guide practice are provided by the MOH, which supervise } \\
\text { independent practices }\end{array}$ \\
\hline Target groups & $\begin{array}{l}\text { - MOH: All Saudis with no restriction, non-Saudis where legal residents and working in the public sector- } \\
\text { universal coverage } \\
\text { - Independent government bodies cover other specific groups }\end{array}$ \\
\hline Comprehensiveness & $\begin{array}{l}\text { - All services available to Saudis: Hospitals, primary care, medical and dental treatment, medications } \\
\text { - Private sector: Comprehensiveness varies }\end{array}$ \\
\hline
\end{tabular}

Table 2. The data on the organisation of the USA healthcare system

\begin{tabular}{ll}
\hline Item & Public and private \\
\hline \multirow{2}{*}{ Delivery } & - Public sector delivered through state and local health departments by government \\
- & Most care delivered through private providers are paid by insurance schemes \\
Ownership & - Private sector is owned by individuals or companies, are independent of each other and self-governing \\
& - Private sector funded through insurance, most often provided by employers or out-of-pocket or via \\
Financing & government schemes (Medicare, Medicaid) \\
& - Personnel: Salaried, fee-for-service or capitation, or a mixture of these \\
& - Facilities: Budgets or fee-for-service, set by owners \\
& - Hospitals provide all services but there are also outpatient centres which offer some specialist treatments \\
& - - Individual practitioners also operate independent offices that offer physician services or other healthcare \\
Organisation & services such as dentistry, optometrists, psychologists, chiropractors and complementary therapies \\
& - Medical laboratories operate independently and contract their services to medical professionals \\
& - Independent medical organisations involved in governance of professions and policy-making \\
Target groups & - Not universal access, only those insured have access \\
Comprehensiveness & - Some hospitals may choose to provide basic care to those uninsured and designate it as charitable \\
& - Estimated to be more than 47 million uninsured people living in America or 1 in 5 Americans
\end{tabular}


Table 3. The data on the organisation of the Australian healthcare system

\begin{tabular}{|c|c|}
\hline Item & Public and private \\
\hline Delivery & $\begin{array}{l}\text { - Public system provided by mixture of Federal, state and local government } \\
\text { - In-hospital and ambulatory care provided free (including elective surgery and medications during stay) } \\
\text { - Private sector delivered by individuals or privately-owned companies through hospitals or practitioners' } \\
\text { premises }\end{array}$ \\
\hline Ownership & $\begin{array}{l}\text { - Government sector owned by government } \\
\text { - Private sector owned by individuals or companies, are independent of each other and self-governing }\end{array}$ \\
\hline Financing & $\begin{array}{l}\text { - Public: Taxation (main source of finance), Medicare levy, Council rates, Grants from Commonwealth to } \\
\text { states } \\
\text { - Hospitals are funded based on coding of the services provided to patients } \\
\text { - Medicare is a compulsory universal health insurance scheme - funded by progressive taxation (covers } \\
\text { around } 16 \% \text { of costs of health care). Provides funding for public hospitals and direct payments to medical } \\
\text { practitioners } \\
\text { - Patients are liable for a 15\% out-of-pocket fee for any outpatient consultation unless the practitioners } \\
\text { participate in 'bulk billing'. Additional safety nets in place for disadvantages families } \\
\text { - No safety nets for private in-hospital fees where Medicare will reimburse } 75 \% \text { - private insurance } \\
\text { available to cover this gap. Partial rebates given for services not available through public healthcare } \\
\text { system }\end{array}$ \\
\hline Organisation & $\begin{array}{l}\text { - Public healthcare: } \\
\text { - Decentralised: Commonwealth funds but states/territories self-govern } \\
\text { - Local governments take responsibility for public health }\end{array}$ \\
\hline Target groups & - All citizens - universal coverage \\
\hline Comprehensiveness & $\begin{array}{l}\text { - Public: Hospitals, primary care, mental health } \\
\text { - Private: Dentists, other allied health professions, community-based services such as home nursing }\end{array}$ \\
\hline
\end{tabular}

Table 4. The data on the organisation of the Singaporean healthcare system

\begin{tabular}{|c|c|}
\hline Item & Public and private \\
\hline Delivery & $\begin{array}{l}\text { - Most hospitals are public, organised into two competing clusters } \\
\text { - Most clinics are private } \\
\text { - Public healthcare is not free but is heavily subsidised }\end{array}$ \\
\hline Ownership & $\begin{array}{l}\text { - Public facilities are government-owned } \\
\text { - Private facilities are owned by individuals or companies and are self-regulating with regards to pricing }\end{array}$ \\
\hline Financing & $\begin{array}{l}\text { - Medical Savings Accounts (MSAs) - individualised superannuation accounts - although this is private } \\
\text { finance, it is monitored and regulated by the government. Represents around } 6 \% \text { to } 8 \% \text { of an individual's } \\
\text { salary, with some contribution from employers } \\
\text { - Employer benefits, government subsidies, out-of-pocket expenses and private insurance fund the } \\
\text { remainder of care } \\
\text { - Facilities receive a global budget based on their historical case-mix per patient treated }\end{array}$ \\
\hline Organisation & $\begin{array}{l}\text { - Centralised: Ministry of Health regulates and monitors the industry and form policy; this includes } \\
\text { monitoring quality of healthcare professional training } \\
\text { - Vertical integration: Patients are stepped down to community hospitals after operations performed in } \\
\text { larger tertiary centres } \\
\text { - Community-based initiatives to co-ordinate a number of private and public providers at all levels with a } \\
\text { focus on certain groups, for example care of the elderly or chronic conditions }\end{array}$ \\
\hline Target groups & $\begin{array}{l}\text { - Universal access - all citizens have access to public healthcare providers but also to private facilities if } \\
\text { they have the means to pay for them } \\
\text { - Focus on public health interventions }\end{array}$ \\
\hline Comprehensiveness & $\begin{array}{l}\text { - Public primary care: Consultation, follow-up from hospital discharge, pharmacy services, public health } \\
\text { including immunisation, screening, education } \\
\text { - Private providers: As for public providers but also complementary and traditional medicines }\end{array}$ \\
\hline
\end{tabular}

The UK provides an example which is similar to the system seen in the KSA, but with some aspects of private provision contracted back to the government, for example infrastructure through the PFI approach, or primary care provided through GP practices which are privately owned. Both of these practices have been heavily criticised, however, due to their costing the NHS much more in the long-term than would be projected if they had maintained control of these services themselves. ${ }^{[33,56,83]}$ This system is the one in which the government bears the most burden, due to the low uptake of private insurance in the UK. This further demonstrates that high levels of government funding must be available to achieve high quality healthcare under this type of system. This further confirms that the publicly-funded system is unlikely to remain sustainable in the context of KSA. 
Table 5. The data on the organisation of the UK healthcare system

\begin{tabular}{ll}
\hline Item & Public and private \\
\hline & - With a focus on public provision which is free at the point-of-use \\
- Public sector delivered by government owned and run hospitals and privately owned GP practices, with \\
- some aspects of provision by not-for-profit organisations such as hospices \\
- Private healthcare provided by practices owned by individuals or companies \\
- Personnel include: doctors, dentists and assistants, nurses, pharmacists, allied health professionals, \\
technical and administrative personnel plus a significant body of management \\
- Hospitals are mostly government-owned \\
- Under some local PFI schemes hospital facilities are owned and operated by private groups which lease \\
these to the government; some services are also contracted out (such as cleaning and catering) \\
- GP practices: Some are owned by the government and employ salaried GPs, others are owned by \\
individuals or companies \\
- Private facilities are owned by individuals or companies \\
- Taxation, NI contributions and prescription charges \\
- Facilities: Segmented budgets set by central directives inside a larger budget structure; additional funding \\
for achieving targets; fines levied for poor standards of care \\
- Personnel: In hospitals are salaried on a nationally standardised scale with some bonuses at the top levels \\
for good performance; some general practitioners (GPs) are salaried while others contract their services \\
independently and are paid on a per-patient basis with bonuses available based on achieving targets \\
- Private: Funded by out-of-pocket expenses or private insurance schemes \\
- Some large private providers exist (such as BUPA) with membership of their private scheme allowing \\
Financing \\
- Vertical integration: Specialist services are provided at tertiary hospitals or other specialist centres \\
- Governance is complex: Central directives from the Department of Health, local policies and executives \\
and clinical governance within local NHS units \\
- All citizens of the UK \\
- Hospitals, primary care, medical treatment all free of charge \\
- Medications, opticians and dental care available at a charge although free for certain groups \\
Target groups
\end{tabular}

Table 6. Contextual information on the populations served by the different healthcare systems

\begin{tabular}{|c|c|c|c|c|c|}
\hline & KSA & USA & Australia & Singapore & UK \\
\hline \multicolumn{6}{|l|}{ Geography } \\
\hline $\begin{array}{l}\text { Area (sq km) } \\
\% \text { in urban areas }\end{array}$ & $\begin{array}{l}2.15 \text { million } \mathrm{km}^{2} \\
82 \%\end{array}$ & $\begin{array}{l}9.834 \text { million } \mathrm{km}^{2} \\
82 \%\end{array}$ & $\begin{array}{l}7.692 \text { million } \mathrm{km}^{2} \\
89 \%\end{array}$ & $\begin{array}{l}719.1 \mathrm{~km}^{2} \\
100 \%\end{array}$ & $\begin{array}{l}242,495 \mathrm{~km}^{2} \\
80 \%\end{array}$ \\
\hline Population & 32.28 million & 323.1 million & 24.13 million & 5.60 million & 65.64 million \\
\hline \multicolumn{6}{|l|}{ Age distribution } \\
\hline $\begin{array}{l}\text { Proportion under } 15 \\
\text { Proportion over } 65\end{array}$ & $\begin{array}{l}28.31 \% \\
2.98 \%\end{array}$ & $\begin{array}{l}18.85 \% \\
15.16 \%\end{array}$ & $\begin{array}{l}18.77 \% \\
15.32 \%\end{array}$ & $\begin{array}{l}15.28 \% \\
12.29 \%\end{array}$ & $\begin{array}{l}17.80 \% \\
17.97 \%\end{array}$ \\
\hline \multicolumn{6}{|l|}{ Human development index } \\
\hline $\begin{array}{l}\text { Life expectancy at birth } \\
\text { GDP per capita (PPP\$) } \\
\text { Mortality rate, infant (per } 1,000 \text { live births) }\end{array}$ & $\begin{array}{l}74 \\
45,489.83 \\
12.5\end{array}$ & $\begin{array}{l}79 \\
45,939.84 \\
6\end{array}$ & $\begin{array}{l}82 \\
36,597.13 \\
3\end{array}$ & $\begin{array}{l}83 \\
57,811.61 \\
2\end{array}$ & $\begin{array}{l}82 \\
33,559.56 \\
4\end{array}$ \\
\hline
\end{tabular}

Table 7. Costs associated with the different healthcare systems

\begin{tabular}{llllll}
\hline & KSA & USA & Australia & Singapore & UK \\
\hline Health expenditure per capita (PPP\$) & 680 & 8,362 & 3,441 & 2,273 & 3,480 \\
Total health expenditure as \% of GDP & 4.7 & 17.1 & 9.4 & 4.9 & 9.1 \\
Per capita government expenditure (\$) & 427 & 4,437 & 2,340 & 1,733 & 2,919 \\
Government expenditure as \% of all healthcare spending & 62.9 & 53.1 & 68 & 36.3 & 83.9 \\
\hline
\end{tabular}

Table 8. The inputs and usage of the different healthcare systems including access to specialist care, primary care facilities and use

\begin{tabular}{llllll}
\hline & KSA & USA & Australia & Singapore & UK \\
\hline Number of physicians per 1,000 people & 2.49 & 2.45 & 3.27 & 1.95 & 2.80 \\
Nurses and midwives per 1,000 people & 4.8 & 9.8 & 10.6 & 5.7 & 8.8 \\
$\begin{array}{l}\text { Hospitals } \\
\quad\end{array}$ & & & & 3 \\
$\quad$ Number of beds per 1,000 people & 2.1 & 2.9 & 3.9 & 4.7 & 3.3 \\
$\quad$ Average acute length of stay days & Not available & 4.9 & 6.0 & 4.7 \\
\hline
\end{tabular}


Table 9. The overall quality of care of the different healthcare systems

\begin{tabular}{llllll}
\hline & KSA & USA & Australia & Singapore & UK \\
\hline Vaccination by 2 years & & & & & \\
DTP (Diptheria/tetanus/pertussis) & $98 \%$ & $95 \%$ & $92 \%$ & $97 \%$ & $96 \%$ \\
Measles & $98 \%$ & $92 \%$ & $94 \%$ & $95 \%$ & $93 \%$ \\
Hib & $98 \%$ & $93 \%$ & $92 \%$ & Not available & $97 \%$ \\
Cancer screening & & & & \\
$\quad$ Breast & Not available & $66 \%$ & $56.2 \%$ & Not available & $75 \%$ \\
Cervical & & Not available & $60.7 \%$ & & $80 \%$ \\
\hline
\end{tabular}

Many countries have adopted a health insurance system to pay for healthcare. There are many variations of the types of scheme adopted, with varied results on the effects on costs and patient outcomes. ${ }^{[40]}$ Two different types of insurance schemes are represented in the data include the social insurance scheme used in Australia and the reliance on private insurance seen in the USA. Australia serves a relatively similar population size to Saudi Arabia, but has a much higher GDP, so can most likely afford to spend more on healthcare. Under their current scheme, the Australian government actually pays more towards healthcare than in KSA. However, a significant proportion of these funds will be generated from input to the social insurance scheme. The quality of care seems to be much higher, but this is also based on a per capita spend which is almost five times that of KSA. Private healthcare should theoretically result in the most efficient provision, as private institutions are run as businesses which seek to maximise their profits and reduce waste. ${ }^{[14]}$ Empirical studies which have sought to compare private with public systems have shown that there may be little difference in reality. ${ }^{[84]}$ In fact, the USA system actually seems to represent the worst of the options which are available. The quality of care seems only comparable to that of Australia and the UK, but has the highest government per capita spend at $\$ 4,437$. In fact, even though the system is supposed to be based predominantly on private insurance, the government currently contributes $53.1 \%$ of spending. It is, however, worth considering that the system seems to contribute significantly to GDP in itself. It is possible that this may simply represent a bad example of a private healthcare system. For example the country may be adversely affected by factors such as the high immigration rates, as immigrants may often be those who are uninsured, so could be associated with higher government costs. ${ }^{[85]}$ Comprehensive studies are, however, difficult, as many of the healthcare systems in the world which rely predominantly on private healthcare are located in low-income countries. This means that there is often only limited data which has been collected on performance, or difficulties accessing this information where it has been collected. ${ }^{[25]}$ This is also complicated by the fact that there seems to be a lack of agreed parameters with which to standardise measurement of health system efficiency, with different studies adopting differing approaches. ${ }^{[84]}$

The best of the options seems to be the PPP approach adopted by Singapore. The quality of care would seem from the limited data available to be very high, yet the government contributes only $36.3 \%$ of spending on healthcare. The remainder comes from the MSA, employer benefits, private insurance schemes or patients themselves. There are, of course, many different aspects of healthcare quality were beyond the scope of this study to include in analysis. The Singaporean healthcare system would seem to deliver on these too though. For example, the Singaporean healthcare system has been described as being highly innovative. It has also been heralded for its provision of patient choice, userfriendliness and timely access to care. ${ }^{[86]}$ One of the major benefits of the PPP approach adopted in Singapore is that it reduce the risk of moral hazard which is observed when healthcare is paid for from insurance, either private or social scheme. ${ }^{[57]}$ Therefore, as patients are ultimately bearing the cost of healthcare themselves in one way or another, it is in their interest to use resources sparingly. The applicability of this system to KSA still requires some evaluation, however, as Singapore seems to be the only nation which has so far been successful in implementing this type of PPP approach. There is some issue over contextual factors which could influence the extent to which the findings may be applicable in practice. It has been argued that evidence-based management may be more difficult to achieve than evidence-based professional practice within healthcare. ${ }^{[87]}$ This is due to the many complexities of the healthcare environment and the social interactions which occur within it, which could significantly influence the outcomes associated with any management decision taken. Therefore, the best practice in one healthcare organisation may not transpire to be best practice in a different organisation. When considering the healthcare system of a nation this would also be argued to extend to cultural, political and economic factors. Gauld ${ }^{[86]}$ identifies the Singaporean government as being highly paternalistic and singular 
in its efforts to exert a shared responsibility. It would be expected that a similar approach may be quite successful in KSA, where the government has also been observed to adopt a paternalistic approach towards welfare improvement. ${ }^{[88]}$

\section{CONCLUSIONS AND RECOMMENDATIONS}

The aim of this study was to compare different models of healthcare financing, based on the results achieved by other countries. The literature review demonstrated that a wide variety of models exist with different mixes of public and private financing and provision. Therefore it is likely that Saudi Arabia will need to consider both components in any future policy changes. Analysis of the systems showed that there is little to support the use of predominantly funded healthcare models based on the experiences of Saudi Arabia and the UK. These models do have some advantage in that they provide equitable access to healthcare which is free at the point-of-delivery. However, they are associated with high levels of expenditure. It would also seem that the rationing which is necessary creates a situation in which richer citizens choose to access private care available, which may then reduce the equity in the system. At the opposite end of the spectrum is the predominantly privately owned and funded approach adopted in the USA. Evidence suggests that while this approach would theoretically be most efficient, in reality it is still associated with huge government costs, due to problems with maintaining access for those in disadvantaged groups. There is also a risk that those who are less risk-averse will not take out insurance if not mandated and will then suffer financial hardship or receive poorer quality care at a later stage. The Australian social insurance model seems to be associated with high quality care, which would suggest there may be some promise for the model. The main advantage is that insurance membership is mandated, with those in employment and their employers contributing most of the cost. There remains an issue of moral hazard with this approach which could see large amounts of money being required to maintain the disadvantaged population. The only system which seems to overcome this problem is that of Singapore, which adopts a PPP approach. This would therefore seem to be the model which would allow KSA to maintain the highest level of healthcare quality while also reducing healthcare costs. However, more in-depth analysis may be required of this system to understand how it would translate to the context of KSA. In particular, care needs to be taken in any system which is selected for adoption so as to reduce the risk of undoing the gains in national healthcare which have been achieved in the recent past. For example there needs to be care to retain high levels of access to primary health, particularly for children, to retain the high levels of vaccination currently observed and prevent communicable disease spread.

On the basis of the findings, the following recommendations are made:

- Healthcare reform: It is clear that the current model of Saudi Arabian healthcare is not sustainable in the future and reform of the system is necessary.

- Research: Further in-depth analysis of the Singaporean healthcare system would be useful to understanding how this would apply in the context of KSA.

- Health insurance model vs. pure privatisation: The health insurance model which has been proposed for the KSA would seem to be preferential to the pure privatisation model adopted in the USA. Steps may need to be taken to reduce the risk of moral hazard as a means to curbing government spending that may still be associated with this model.

\section{CONFliCtS OF INTEREST Disclosure}

The author declares no conflicts of interest.

\section{REFERENCES}

[1] Baranowski J. Health systems of the world - Saudi Arabia profiling a consultant's view of the health care system of Saudi Arabia. Global Health. 2009; 2(1): 1-8.

[2] Jannadi B, Alshammari H, Khan A, et al. Current structure and future challenges for the healthcare system in Saudi Arabia. Asia Pacific Journal of Health Management. 2008; 3: 43-50.

[3] Al Salloum N, Cooper M, Glew S. The development of primary care in Saudi Arabia. InnovAiT: Education and inspiration for general practice. 2015; 8: 316-318. https://doi.org/10.1177/175573 8014523575

[4] Elachola H, Memish ZA. Oil prices, climate change-health challenges in Saudi Arabia. Lancet. 2016; 387: 827-829. https ://doi.
org/10.1016/S0140-6736(16) 00203-8

[5] Ministry of Health. Health statistical year book. Available from: http://www.moh.gov.sa/en/Ministry/Statistics/ book/Pages/default . aspx [Accessed 25 May 2017].

[6] Aldossary A, While A, Barriball L. Health care and nursing in Saudi Arabia. International Nursing Review. 2008; 55: 125-128. PMid: 18275546. https://doi.org/10.1111/j.1466-7657.2007.0 0596. $\mathrm{x}$

[7] Albejaidi FM. Healthcare system in Saudi Arabia: An analysis of structure, total quality management and future challenges. Journal of Alternative Perspectives in the Social Sciences. 2010; 2(2): 794-818.

[8] Aleklett K, Hook M, Jakobsson K, et al. The peak of the Oil Age - analysing the world oil production reference scenario in World 
Energy Outlook 2008. Energy Policy. 2010; 38(3): 1398-1414. https://doi.org/10.1016/j.enpol.2009.11.021

[9] Almalki M, Fitzgerald G, Clark M. Health care system in Saudi Arabia: an overview. Eastern Mediterranean Health Journal. 2011; 17(10): 784-793. PMid: 22256414.

[10] Marmor T, Oberlander J, White J. The Obama Administration's options for health care cost control: Hope versus reality. Annals of Internal Medicine. 2009; 150: 485-489. PMid: 19258549. https: //doi.org/10.7326/0003-4819-150-7-200904070-00114

[11] Shortell SM, Rundall TG, Hsu J. Improving patient care by linking evidence-based medicine and evidence-based management. JAMA 2007; 298(6): 673-676. PMid: 17684190. https://doi.org/10 $.1001 /$ jama.298.6.673

[12] Tawfik-Shukor AR, Klazinga NS, Arah OA. Comparing health system performance assessment and management approaches in the Netherlands and Ontario, Canada. BMC Health Services Research. 2007; 7: 25. PMid: 17319947. https://doi.org/10.1186/1472 $-6963-7-25$

[13] Morris S, Devlin N, Parkin D. Economic Analysis in Health Care Chichester: John Wiley \& Sons Ltd; 2007.

[14] McPake B, Normand C, Smith S. Health economics: an international perspective. Abingdon: Routledge; 2013.

[15] Lim MK. Transforming Singapore health care: Public-private partnership. Annals of Academic Medicine of Singapore. 2005; 34: 461-467. PMid: 16123824.

[16] Blomqvist A. Social health insurance: Government funding of health care. In Lu M, Jonsson E. (eds.) Financing Health Care: New Ideas for a Changing Society (pp. 17-48). Germany: Wiley; 2008.

[17] Laurell AC. An Overview of Latin American Health Policies and Debates. Social Medicine. 2010; 5(1): 50-57.

[18] Pashardes P, Pashourtidou N. Consumer welfare from publicly supplemented private goods: Age and income effects on demand for health care. Empirical Economics. 2011; 41: 865-885. https: //doi.org/10.1007/s00181-010-0410-7

[19] Qutub AF, Al-Jewair TS, Leake JL. A comparative study of the health care systems of Canada and Saudi Arabia: Lessons and insights. International Dental Journal. 2009; 59: 277-283. PMid: 19998662.

[20] Ter Meulen R. How 'decent' is a decent minimum of health care? Journal of Medicine \& Philosophy. 2011; 36(6): 612-623. PMid: 22241865. https://doi.org/10.1093/jmp/jhr048

[21] Field MG. The concept of the "health system" at the macrosociological level. Social Science and Medicine. 1973; 7(10): 763-785. https://doi.org/10.1016/0037-7856(73)90118-2

[22] Terris M. The three world systems of medical care: Trends and prospects. American Journal of Public Health. 1978; 68(11): 1125 1131. PMid: 717620. https://doi.org/10.2105/AJPH.68.11 .1125

[23] Frenk J, Donabedian A. State intervention in medical care: Types, trends and variables. Health Policy and Planning. 1987; 2(1): 17-31. PMid: 10282125. https://doi.org/10.1093/heapol/2.1.17

[24] Wendt C, Frisina L, Rothgang H. Healthcare system types: A conceptual framework for comparisons. Social Policy \& Administration. 2009; 43(1): 70-90. https ://doi.org/10.1111/j.1467-9515. $2008.00647 . \mathrm{x}$

[25] Forsberg BC, Montagu D, Sundewall J. Moving towards in-depth knowledge on the private health sector in low- and middle-income countries. Health Policy and Planning. 2011; 26: 11-13. PMid: 21729912. https://doi.org/10.1093/heapol/czr050

[26] Sebai ZA, Milaat WA, Al-Zulaibani AA. Health care services in Saudi Arabia: Past, present and future. Journal of Family \& Community Medicine. 2001; 8(3): 19-23. PMid: 23008647.
[27] Khaliq AA. The Saudi healthcare system: A view from the minaret. World Health \& Population. 2012; 13(3): 52-64. PMid: 22555119. https://doi.org/10.12927/whp.2012.22875

[28] Iglehart JK. Revisiting the Canadian health care system. New England Journal of Medicine. 2000; 342(26): 2007-2012. PMid: 10874071. https://doi.org/10.1056/NEJM20000629342262 4

[29] Gorsky M. The British National Health Service 1948-2008: a review of the historiography. Social History of Medicine. 2008; 21(3): 437-460. https://doi.org/10.1093/shm/hkn064

[30] Courbage C, De Coulon A. Prevention and private health insurance in the UK. The Geneva papers on risk and insurance issues and practice. 2004; 29(4): 719-727. https://doi .org/10.1111/j .1468-044 $0.2004 .00313 . \mathrm{x}$

[31] HM Revenue and Customs. National Insurance Fund Account 201516 [Internet]. Available from: https://www.gov.uk/governmen t/publications/national-insurance-fund-accounts [Accessed 22 May 2017].

[32] Mastrobuono I, Visconti G, Sorbara D, et al. European evolution of the copayment in health costs: Possible developments and reorganization proposals for Italian health care system. The role of additional kind of assistance. Igiene e Sanita Pubblica. 2012; 68(2): 155. PMid: 23064088.

[33] Gaffney D, Pollock AM, Price D, et al. NHS capital expenditure and the private finance initiative - expansion or contraction?. BMJ. 1999; 319(7201): 48-51. PMid: 10390465. https://doi.org/10.113 $6 / \mathrm{bmj} .319 .7201 .48$

[34] Hart JT. Which future for the UK National Health Service (NHS)? Michael Quarterly. 2011; 8: 442-459.

[35] Harley K, Willis K, Gabe J, et al. Constructing health consumers: Private health insurance discourses in Australia and the United Kingdom. Health Sociology Review. 2011; 20(3): 306-320. https : //doi.org/10.5172/hesr.2011.20.3.306

[36] Pollock AM, Price D, Liebe M. Private finance initiatives during NHS austerity. BMJ. 2011; 342(2): d324. PMid: 21307102 https://doi.org/10.1136/bmj.d324

[37] Doran T, Fullwood C, Kontopantelis E, et al. Effect of financial incentives on inequalities in the delivery of primary clinical care in England: Analysis of clinical activity indicators for the quality and outcomes framework. The Lancet. 2008; 372(9640): 728-736. https://doi.org/10.1016/S0140-6736(08)61123-X

[38] Adams CP, Brantner VV. Estimating the cost of new drug development: Is it really $\$ 802$ million?. Health Affairs. 2006; 25(2): 420428. PMid: 16522582 . https ://doi.org/10.1377/hlthaff .25 .2 .420

[39] Buntin MB, Burke MF, Hoaglin MC, et al. The benefits of health information technology: A review of the recent literature shows predominantly positive results. Health Affairs. 2011; 30(3): 464471. PMid: 21383365 . https://doi.org/10.1377/hlthaff. 20 11.0178

[40] Schoen C, Osborn R, Squires D, et al. How health insurance design affects access to care and costs, by income, in eleven countries. Health Affairs. 2010; 29(12): 2323-2334. PMid: 21088012 https://doi.org/10.1377/hlthaff .2010.0862

[41] Besley T, Hall J, Preston I. The demand for private health insurance: Do waiting lists matter? Journal of Public Economics. 1999; 72(2): 155-181. https://doi.org/10.1016/S0047-272 7 (98) 00108-X

[42] Butler JRG. Policy change and private health insurance: Did the cheapest policy do the trick? Australian Health Review. 2002; 25(6): 33-41. PMid: 12536860. https://doi.org/10.1071/AH020033 
[43] Evans H. Government oversight of comparative effectiveness: Lessons from Western Europe. In Atlas, S.W. (ed.) Reforming America's Health Care System: The Flawed Vision of ObamaCare (pp. 145-166). Stanford: Hoover Institution Press; 2010.

[44] Niles NJ. Basics of the U.S. Health Care System. London: Jones and Bartlett Learning; 2016.

[45] Brown ER, Lavarrada SA. Public policies to extend health care coverage. In Andersen et al. (eds.) Changing the U.S. Health Care System: Key Issues in Health Services Policy and Management (pp. 81-116). San Francisco: Jossey-Bass; 2007.

[46] Phelan JC, Link BG, Tehranifer P. Social conditions as fundamental causes of health inequalities: Theory, evidence, and policy implications. Journal of Health and Social Behavior. 2010; 51(1): S28S40. PMid: 20943581. https://doi.org/10.1177/00221465 10383498

[47] Cuff K, Hurley J, Mestelman S, et al. Public and private health-care financing with alternate public rationing rules. Health Economics. 2012; 21(2): 83-100. PMid: 22223554. https://doi.org/10.1 $002 /$ hec. 1698

[48] Chen TC, Vahid F. Demand for Hospital Care and Private Health Insurance in a Mixed Public-Private System: Empirical Evidence Using a Simultaneous Modeling Approach. Melbourne Institute Working Paper No. 22/11: 2011. Available from: http://papers.ssrn.co m/sol3/papers.cfm?abstract_id=1752581 [Accessed 29 May 2017].

[49] Resneck J, Pletcher MJ, Lozano N. Medicare, Medicaid, and access to dermatologists: The effect of patient insurance on appointment access and wait times. Journal of the American Academy of Dermatology. 2004; 50(1): 85-92. https ://doi .org/10.1016/S019 0-9622 (03) 02463-0

[50] Hadley J, Holahan J, Coughlin T, et al. Covering the uninsured in 2008: Current costs, sources of payment, and incremental costs. Health Affairs. 2008; 27(5): w399-w415. PMid: 18725375. https: //doi.org/10.1377/hlthaff.27.5.w399

[51] Woolhandler S, Campbell T, Himmelstein DU. Cost of health care administration in the United States and Canada. New England Journal of Medicine. 2003; 349(8): 768-775. PMid: 12930930. https://doi.org/10.1056/NEJMsa022033

[52] Tandon A, Murray CJ, Lauer JA, et al. Measuring overall health system performance for 191 countries. Geneva: World Health Organization; 2000.

[53] Fisher ES, Bynum JP, Skinner JS. Slowing the growth of health care costs - Lessons from regional variation. New England Journal of Medicine. 2009; 360(9): 849-852. PMid: 19246356. https: //doi.org/10.1056/NEJMp0809794

[54] Graham JR. Should your state establish an Obamacare Health Insurance Exchange?'. Health Policy Prescriptions. 2010; 8(10): 1-5.

[55] Nishtar S. Public-private 'partnerships' in health - a global call to action. Health Research Policy and Systems. 2004; 2(1): 5. PMid: 15282025. https://doi .org/10.1186/1478-4505-2-5

[56] Hellowell M, Pollock AM. The private financing of NHS hospitals: Politics, policy and practice. Economic Affairs. 2009; 29(1): 13-19. https://doi.org/10.1111/j.1468-0270.2009.01861.x

[57] Lim MK. Shifting the burden of health care finance: A case study of public-private partnerships in Singapore. Health Policy. 2004; 69(1): 83-92. PMid: 15484609. https://doi.org/10.1016/j.health pol.2003.12.009

[58] Hellowell M, Vecchi V. An evaluation of the projected returns to investors on 10 PFI projects commissioned by the National Health Service. Financial Accountability \& Management. 2012; 28(1): 77-100. https://doi.org/10.1111/j.1468-0408.2011.00537.x

Published by Sciedu Press
[59] Kothari CR. Research Methodology: Methods \& Techniques (2nd edn). Delhi: New Age International Publishers; 2004.

[60] McIntosh E, Adamowicz WL, Johnson FR. The relevance of costbenefit analysis in health care: Concluding comments. In McIntosh, E., Clarke, P., Frew, E.J. and Louviere, J.J. (eds.) Applied Methods of Cost-Benefit Analysis in Health Care (pp. 259-262). Oxford: Oxford University Press; 2010.

[61] Johannesson M, Jonsson B. Economic evaluation in health care: Is there a role for cost-benefit analysis?. Health Policy. 1991; 17(1): 1-23. https: //doi .org/10.1016/0168-8510 (91) 90114-D

[62] Schultz TP. Assessing the productivity benefits of nutrition and health: An integrated human capital approach. Journal of Economics. 1997; 77: 141-158. https://doi.org/10.1016/S0304-4076(96) 018 10-6

[63] Eichler HG, Kong SX, Gerth WC, et al. Use of cost-effectiveness analysis in health-care resource allocation decision-making: How are cost-effectiveness thresholds expected to emerge?. Value in Health. 2004; 7(5): 518-528. PMid: 15367247. https ://doi.org/10.1 $111 / \mathrm{j} .1524-4733.2004 .75003 . \mathrm{x}$

[64] Burton WN, Conti DJ, Chen CY, et al. The role of health risk factors and disease on worker productivity. Journal of Occupational \& Environmental Medicine. 1999; 41(10): 863-877. PMid: 10529942. https://doi.org/10.1097/00043764-199910000-00007

[65] Gift TL, Marrazzo J. Cost-effectiveness analysis. In Aral, S.O and Douglas, J.M. (eds.) Behavioral Interventions for Prevention and Control of Sexually Transmitted Diseases (pp. 482-499). New York: Springer; 2007. https://doi.org/10.1007/978-0-387 -48740-3_21

[66] Neumann PJ. Costing and perspective in published cost-effectiveness analysis. Medical Care. 2009; 47(7): S28-S32. PMid: 19536023 https://doi.org/10.1097/MLR.0b013e31819bc09d

[67] Neumann PJ, Palmer JA, Daniels N, et al. A strategic plan for integrating cost-effectiveness analysis into the US healthcare system. The American Journal of Managed Care. 2008; 14(4): 185-188. PMid: 18402510.

[68] Davis JC, Marra CA, Robertson MC, et al. Economic evaluation of dose-response resistance training in older women: A costeffectiveness and cost-utility analysis. Osteoporosis International. 2011; 22: 1355-1366. PMid: 20683707. https ://doi.org/10.1 007/s00198-010-1356-5

[69] Revesz RL, Livermore MA. Retaking Rationality: How Cost-Benefit Analysis Can Better Protect the Environment and Our Health. Oxford: Oxford University Press; 2008.

[70] Weatherly H, Drummond M, Claxton K, et al. Methods for assessing the cost-effectiveness of public health interventions: Key challenges and recommendations. Health Policy. 2009; 93(2-3): 8592. PMid: 19709773. https://doi.org/10.1016/j.healthpo 1.2009 .07 .012

[71] Feacham RG, Sekhri NK, White KL. Getting more for their dollar: A comparison of the NHS with California's Kaiser Permanente. BMJ. 2002; 324(7330): 135-141. https://doi.org/10.1136/bmj. 32 4.7330 .135

[72] Halpern NA, Pastores SM. Critical care medicine in the United States 2000-2005: An analysis of bed numbers, occupancy rates, payer mix, and costs. Critical Care Medicine. 2010; 38(1): 6571. PMid: 19730257. https://doi.org/10.1097/CCM.0b013e 3181b090d0

[73] Smith PC, Mossialos E, Papanicolas I. Performance Measurement for Health System Improvement: Experiences, challenges and prospects. Copenhagen: WHO; 2008.

[74] Bryman A, Bell E. Business Research Methods (2nd edn). Oxford: Oxford University Press; 2007. 
[75] Babbie E. The Practice of Social Research (12th edn). Belmont: Wadsworth; 2010.

[76] Organisation for Economic Co-operation and Development (OECD). Average length of stay in hospitals. 2015. Available from: https://data.oecd.org/healthcare/length-of-hos pital-stay.htm [Accessed 6 July 2017].

[77] World Health Organization (WHO). Countries. 2017. Available from: http://www. who. int/countries/en/ [Accessed 26 June 2017].

[78] World Bank. 2017. Available from: https://data.worldbank.o rg/ [Accessed 26 June 2017].

[79] Jacobsen KH. Introduction to Health Research Methods: A Practical Guide. London: Jones \& Bartlett Learning International; 2012.

[80] Popkin BM, Doak CM. The obesity epidemic is a worldwide phenomenon. Nutrition Reviews. 1998; 56(4): 106-114. PMid: 9584495. https://doi.org/10.1111/j.1753-4887.1998.tb01722.x

[81] Shaw JE, Sicree RA, Zimmet PZ. Global estimates of the prevalence of diabetes for 2010 and 2030. Diabetes Research and Clinical Practice. 2010; 87(1): 4-14. PMid: 19896746. https://doi.org/10 $.1016 /$ j.diabres.2009.10.007

[82] Barrage G, Perillieux R, Shediac R. Investing in the Saudi Arabian Healthcare Sector. Abu Dhabi: Booz \& Co; 2007.
[83] Fleetcroft R, Cookson R. Do the incentive payments in the new NHS contract for primary care reflect likely population health gains? Journal of Health Services Research \& Policy. 2006; 11(1): 27-31. PMid: 16378529. https://doi.org/10.1258/135581906775094316

[84] Joumard I, Andre C, Nicq C. Health care systems: Efficiency and institutions, OECD Economics Department Working Paper No. 769; 2010. Available from: http://papers.ssrn. com/sol3/papers . cfm?abstract_id=1616546 [Accessed 20 May 2017].

[85] Derose KP, Bahney BW, Lurie N, et al. Review: Immigrants and health care access, quality, and cost. Medical Care Research and Review. 2009; 66(4): 355-408. PMid: 19179539. https://doi.or g/10.1177/1077558708330425

[86] Gauld R. The health care system in Singapore. In Aspalter, C. et al. (eds.) Health Care Systems in Europe and Asia. Abingdon: Routledge; 2012.

[87] Arndt M, Bigelow B. Evidence-based management in health care organizations: A cautionary note. Health Care Management Review. 2009; 34(3): 206-213. PMid: 19625822. https ://doi.org/10.1 097/HMR . 0b013e3181a94288

[88] Auty RM. The political state and the management of mineral rents in capital-surplus economies: Botswana and Saudi Arabia. Resources Policy. 2001; 27(2): 77-86. https://doi.org/10.1016/S030 1-4207 (01) 00008-3 